УДК 351:316.614.5:305(477)

DOI 10.36910/6775-2313-5352-2021-18-5

Григор'єва, Н.С., Гуменюк Л.О., Марчук І.В., Собчук Д.С., Шабайкович В.А.

Луцький національний технічний університет

\title{
ВПЛИВ ПАНДЕМІЇ КОРОНАВІРУСУ НА ВИРОБНИЦТВО ТА МЕДИЧНЕ ОБСЛУГОВУВАННЯ
}

Розглянуто заходи боротьби з пандемією коронавірусу при лікуванні захворювання коронавірусом, організаџії нормального функиіонування виробнищтва та адаптації соџіальної сфери обслуговування. Периий напрямок - основний, пов'язаний із заходами підготовки медичного персоналу, ліків, обладнання, оснащення, спеціалістів-лікарів, тестування, вакиинації. Досягається виключно при комплексному аналізі та синтезі рівня медицини, конструкції та технології виробів, організащії виготовлення, внутрішнього та зовнішнього середовища. Забезпечення нормального функиіонування виробництва досягається иляхом його реорганізаиії, дезінфекиії виробничих потужностей, використання автоматичного обладнання та оснащення, захист виробничого персоналу тощо. Зміни в соиіальній сфері обслуговування включають ї̈ адаптацію до пандемії коронавірусу, реорганізацію транспортних потоків, послуг, заборони, обмеження та пристосованість до навколишнього середовища. Обов'язкове врахування причин пандемї коронавірусу.

Ключові слова: коронавірус, медииина, пандемія, заходи, заборони.

\section{Постановка проблеми}

Серед багатьох проблем сучасності несподівано виникла гостра проблема пандемії коронавірусу, котра вплинула на всі сфери життя. По-перше, точно невідомо звідкіля взявся коронавірус. Версія, що він вийшов з ринку Уханя в Китаї, не витримує ніякої критики: хоча б серед перших 41 зареєстрованих хворих, заражених новим коронавірусом, безпосередній контакт із ринком в Ухані мали лише 27 людей. Не причому тут і зараження від кажанів і змій, оскільки раніше саме таких заражень не спостерігалось. По-друге, взаємні обвинувачення між Китаєм та США про зараження без наведення будь-яких доказів виглядають натягнуто. Залишаються лабораторії біологічної зброї, але і тут одні припущення, як і в інших випадках. Шкода, що нема ще посилань на космос, інфраструктуру, атмосферу тощо. Перший коронавірус людини було виділено у 1965 році вченими D.Tyrrell та M. Вуnое від хворих на гостру респіраторну вірусну інфекцію. Самостійна родина коронавірусів була сформована у 1968 році. Побудова варіона коронавіруса SARS-CoV-2 наведена на рис. 1. Діаметри різних вірусів коливаються в межах 80-220 нм, походження зовнішньої форми невідоме. Кінцева частина кожного шипа "імітує" молекулу корисної речовини, тому клітинні рецептори самі затягують їі у себе, а за шипом до клітини потрапляє весь вірус. Механізм зараження організму коронавірусом полягає в тому, що при інфікуванні білковий шип на поверхні вірусу SARSCoV2 прикріплюється до білка-рецептора на поверхні клітин людини і проникає в них [1].

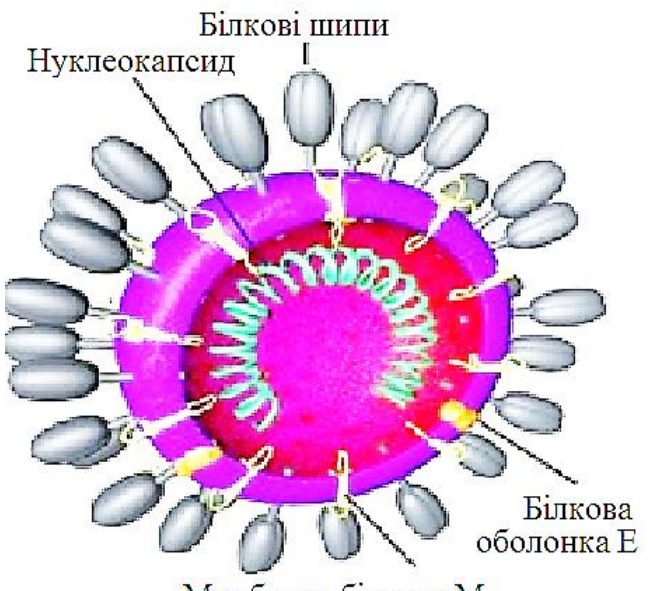

Мембрана білкова М

Рис. 1. Побудова віріона коронавіруса SARS-CoV-2
Метою статті $є$ покращення довкілля в умовах пандемії коронавіруса за рахунок заходів і зменшених витрат на антикризову боротьбу з окремими іiі частинами: технічною, медичною та соціальною.

Викладення основного матеріалу дослідження Причинами зараження коронавірусом є мутації, в результаті яких появляється новий тип вірусу. Джерелом коронавірусної інфекції, як правило, $\epsilon$ хвора людина. При цьому, період контагіозності невизначено довгий. Джерелом коронавірусу можливо можуть бути також деякі тварини (мавпи, птахи, змії та інші). Джерелом нового типу збудника (2019-nCoV) малоймовірно вказуються кажани. При цьому, тепер немає даних про те, що домашні тварини (такі, як щури, собаки чи коти) можуть переносити коронавірус. Збудники можуть передаватися 
безпосередньо через предмети, дверні ручки, посилки, продукти, якщо не дотримана гігієна рук і правила кулінарної обробки продуктів. Не можна торкатися забрудненими руками та предметами обличчя, носа, рота, очей. Тому руки рекомендується часто та ретельно мити 3 милом або обробляти дезінфікуючими засобами. Відмічається нова стратегія коронавіруса, при якій немає ні підвищення температури, ні кашлю, ні болю. Зафіксовано випадки безсимптомного розвитку коронавіруса, яке виявляє КТ, тобто вірус діє далі та нищить легені. Що саме спричиняє такий перебіг коронавірусної хвороби невідомо. Генетики пояснюють це можливою мутацією коронавірпусу, тобто це для них поки що теж невідомо. До того, розповсюдження коронавірусу почалось раніше до офіційного його оголошення.

Вірус передається в основному повітряно-крапельним, повітряно-пиловим і контактним способом і можливо ще якимсь іншим. В сухому стані вірус не передається. У зв'язку з багатьма невідомими протікання коронавірусної інфекції кількість фейкових і абсурдних новин значно зросла. Зросла також кількість безглуздих заходів і обмежень.

Поки що подолати пандемію коронавіруса можна лише вакцинацією, альтернативи якій немає. Зараз у світі відомо до 50 різновидів вакцин з різними характеристиками. Серед них Pfizer та BioNTech, BNT162b2, Moderna, AstraZeneca, Спутнік V, QazCovid-in, CoronaVac. Ïx ефективність коливається в межах 70\% - 95\%._Мутація коронавірусів приводить до неефективності застосування відомих вакцин. Причини мутації коронавірусу невідомі, припускається, що вони зв'язані з його здатністю пристосовуватись до організму людини та їі імунної системи. Такі припущення поки що також передбачувані.

В Австрії, Англії, Данії, Нідерландах, ЮАР та інших країнах появився новий штам коронавірусу COVID-19 більш заразний (на 70\%), швидко поширюваний, невразливий до відомих вакцин. Нові штами коронавірусів пов'язані з їх мутацією, зменшити яку можна лише зупинкою пандемії вакцинацією, режимом карантину, особистою гігієною. В США було створено антитіло ADG, яке зв'язується не лише з збудником COVID-19, а з більшістю його родинних видів. Відомий експериментальний препарат REGN-COV-2, котрий успішно лікує коронавірус і яким вилікували Дональда Трампа, Джуліані та інших. Його дія базується на моноклональних антитілах. Появився також препарат Bamianivimab i Baricitinib.

Заходи боротьби з пандемією коронавіруса SARS-CoV-2, яка створила цілий ряд різнопланових загроз для навколишнього середовища, оцінка яких є складною та ймовірною. Навіть вже на цьому етапі необхідність подолання пандемії COVID-19 порушила цілий ряд гострих проблем [2]. Такі заходи можна згрупувати безпосередньо для хвороби коронавіруса, функціонування виробництва продукції, соціальних заходів тощо, хоча вони є умовними оскільки відображаються на розвитку навколишнього середовища та потребують відповідного фінансування. Причому на практиці на різних етапах боротьби з поширенням коронавіруса SARS-CoV-2 та проявами пандемії COVID-19 згаданих категорії, заходи можуть бути різними. На початку поширення пандемії COVID-19 на перший план вийшли технічно-організаційні проблеми, пов'язані з переміщенням людських потоків, контролем стану їхнього здоров'я, організацією карантину, роботи медичних закладів у нових умовах, організацією відповідних медичних досліджень тощо. При цьому виняток складають інформаційно-психологічні загрози, які супроводжують всі процеси життєдіяльності.

Проявляються також соціальні та особливо фінансово-економічні проблеми боротьби 3 коронавірусом. Гострішою стає проблема знаходження додаткового фінансування для протидії поширенню коронавіруса та перерозподілу відповідних фінансових і матеріальних ресурсів між різними об'єктами за рахунок резервних фондів державної та місцевої влади, спонсорської допомоги тощо. Треба буде обов'язково враховувати відомий іноземний досвід недопущення негативного перебігу подій 3 подоланням технічно-організаційних i iнформаційнопсихологічних загроз. Саме технічно-організаційна сфера боротьби з поширенням пандемії потребує фінансових ресурсів для тестів для перевірки пацієнтів на наявність коронавірусу.

Велике значення має правильне тестування для успішної боротьби 3 поширенням коронавірусу та пандемії особливо для медичного персоналу. При цьому, підвищенню захворювання на коронавірус є неправильне тестування населення. Саме належна організація тестування населення набуває особливого значення для успішної боротьби 3 поширенням

(C) Григор’єва, Н.С, Гуменюк, Л.О, Марчук, І.В., Собчук, Д.С., Шабайкович, В.А. 
пандемії коронавіруса. За рівнем тестування населення на інфікування коронавіруса Україна значно відстає від країн Європи. Вона єдина, яка ще не почала вакцинування. Відмічається істотне збільшення кількості тестувань методом ПЛР, яке практикується останнім часом. Розширення тестування населення на наявність коронавірусу $є$ необхідним як з медичних, так і 3 економічних критеріїв. До того ж всі ці заходи крім потреби відповідного фінансування впливають на перебіг економічних процесів. Економічні витрати від заходів боротьби 3 пандемією коронавіруса можуть бути більшими за негативні економічні наслідки самої пандемії. При цьому ситуація знаходиться між необхідністю стримувати пандемію та при цьому не зруйнувати все технічне, економічне та соціальне життя в країні. Тепер повстала необхідність розробки стратегічно орієнтованого плану в економіці, заходи якого включатимуть не тільки суто економічні, фінансові, але і соціальні, гуманітарні, науковотехнологічні тощо.

Таким чином, розглядаючи ситуацію у світі, можна відмітити складну взаємопов'язану систему: пандемія коронавірусу, що складається з самої хвороби коронавірусу, технології лікування, матеріально-лікувальної бази, наявних ліків, спеціалістів, науково-дослідної роботи. Всі складові тісно пов'язані між собою, а особливо функціонуванням МО3, фінансуванням тощо. Особливо це стосується реорганізації МО3.

Велике значення при пандемії має також виробництво, як засіб життя. Приймались неправильні рішення, які в основному зводились до його закриття. Якщо буде розроблена та впроваджена повітряна дезінфекція приміщень, то всі виробничі приміщення, як і інші, можуть бути дезінфіковані при умові їх ущільнення. Але тут потрібні будуть інноваційні розробки і додаткове оснащення з обладнанням тощо.

Виробництво - це процес створення матеріальних і суспільних благ, необхідних для існування та розвитку. Така лінія (рис. 2) працює без робітників, але з наладчиками, яких

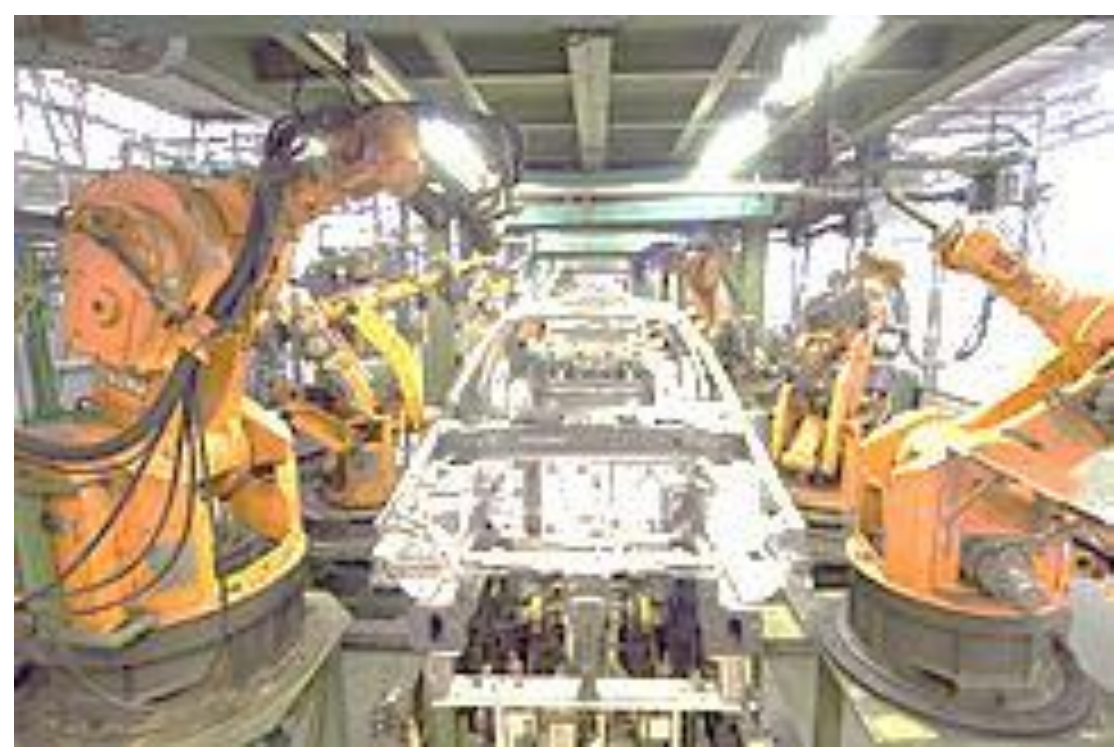

Рис.2. Роботизована лінія виробництва автомобілів потрібно набагато менше. Процес виробництва за своєю структурою складається 3 таких частин: власне виробництво, основне виробництво, виробнича інфраструктура, соціальна інфраструктура, розподіл, обмін, споживання. Таким чином, ця система включає людський потенціал, продукцію, технологію виготовлення, матеріально-технічну базу тощо. Як виробництво реагує на коронавірусну пандемію? Найпростіше -

скороченням чи взагалі закриття виробництва та при цьому виданням зарплати непрацюючому персоналу, тобто за ніщо, що приводить до економічного колапсу, ліквідації сотень тисяч робочих місць та значного погіршення рівня життя населення. Систему творять виробничі відносини, суть виробництва, різні чинники, засоби і способи виробництва, виробничий цикл, підготовка виробництва та виготовлення нових чи пристосованих конструкцій. Це досить складна система.

Виробництво продукції при коронавірусі в першу чергу опирається на його повній підготовленості до функціонування, адаптації. Не кожну продукцію можна виготовляти в таких умовах і тому зосереджуються на іiі структурі, властивостях, особливо взаємодією 3 
навколишнім середовищем. Однозначно, технологія одержання продукції має бути антикоронавірусною, як з точки зору відповідності матеріально-технічної бази, організації виробництва і особливо керівного та робочого персоналу. Всі виробничі приміщення повинні бути ізольованими, а повітря та обладнання провентильоване та обов'язково продезинфінковане, додатково робітники постачені засобами індивідуального та колективного захисту, як це роблять зарубіжні фірми.

Наприклад, фiрма Boeing зменшила виробництво та скоротила на $10 \%$ персонал у зв'язку 3 коронавірусом [3]. Компанія зменшила виробництво лайнерів 787 удвічі - до семи літаків на місяць - до 2022 року і відновить виробництво літаків 737 MAX у невеликому обсязі в поточному році, а до 2021 року збільшить його до 31 літаків за місяць. Свропейський аерокосмічний концерн Airbus SE на початку квітня також прийняв рішення про скорочення виробництва. Компанія повідомила, що зменшить випуск літаків на третину у зв'язку 3 пандемією коронавіруса. Boeing планувала виробляти приблизно в два рази більше лайнерів 737 MAX. Також компанія скорочує обсяг виробництва літаків Boeing 777. Раніше в компанії працювало 161 тис. людей. Пандемія коронавіруса завдала бізнесу важкий удар, позначаючись на попиті з боку авіакомпаній, безперервності виробництва, а також стабільності ланцюжка поставок повідомив головний виконавчий директор Boeing Девід Келхун у листі співробітникам.

Великі автомобільні компанії також призупинили виробництво в Свропі через пандемію [4]. Також про припинення роботи на території Іспанії та Франції повідомили у прес-службі одного 3 найбільших авіабудівельних заводів світу. Зупинка виробництва Volkswagen триватиме два тижні Facebook/volkswagen У Європі через оголошення пандемії у зв'язку з коронавірусом виробництво припинили такі великі автоконцерни як Volkswagen, Fiat, Renault i PSA Group. Про це повідомляє_видання Meduza. Всього 35 підприємств автомобільного виробництва повідомили про вимушене припинення роботи через пандемію, що було неправильно. Крім цього, про плани призупинення виробництва в Іспанії та Франції повідомляють у прес-службі авіакомпанії Airbus та заміни іншою продукцією, потрібною при пандемії, наприклад медичною.

Значним поступом була розробка маски, котра діагностує зараженням коронавірусом за допомогою спеціальних чуйииків, які відслідковують основні параметри здоров'я людини [5]. Реєструється температура, насичення крові киснем, артеріальний тиск і частота серцевих скорочень, які $\epsilon$ основними при первинному визначенні коронавіруса. Чуйники знаходяться в постійному зіткненні зі шкірою людини, усунувши контакт 3 хворим i забезпечивши віддалений контроль і передачу даних в реальному часі на смартфон.

Була також розроблена цікава антибактеріальна маска 3 графену [6]. Фактично це інтегрована система моніторингу, в якій чутливі чуйники, перебувають в постійному контакті зі шкірою людини, реєструють показники, що $\epsilon$ основними при первинному визначенні коронавіруса COVID-19. Вказується, що маски впоралися 3 ліквідацією двох видів коронавірусів, причому, для створення масок вчені користувалися власним, спрощеним методом отримання графену з використанням лазера. Експеримент показав, що 99,7\% вірусу SARS-CoV-2 було знищено після 30 секундного впливу короткохвильового ультрафіолетового випромінювання 3 довжиною хвилі 222 нм і щільністю теплового потоку $0,1 \mathrm{mBT} / \mathrm{cm}^{2}$.

Американські вчені розробили багаторазову маску з підігрівом [7], яка знищує віруси. В маску вбудована мідна сітка, котра підігрівається. При диханні повітря проходить через сітку, яка вбиває вірусні частинки високою температурою. Інноваційний гігієнічний пристрій допоможе медикам, які постійно контактують з хворими на коронавірус, а також стане в нагоді людям у випадках неможливості дотримування соціальної дистанції, наприклад, в транспорті в годину пік тощо. Концепція роботи маски відрізняється від інших тим, що не стримує проходження вірусу через маску, а уповільнює його рух і знищує.

Ряд підприємств замість закриття також змінюють продукцію на потрібну для боротьби 3 коронавірусом [8]. Так, автомобільні концерни почали випускати медичні апарати ШВЛ, а лікеро-горілчані заводи, текстильні фабрики - антисептики і захисні маски. У зв’язку 3 пандемією коронавіруса багато світових компаній перенаправили частину свого виробництва на виготовлення життєво важливих засобів захисту, медичного обладнання та оснащення. Американські компанії Old Fourth Distillery та Moonrise Distillery, що спеціалізувалися на виробництві спиртних напоїв, почала виробляти антисептики для рук. Група Kering, один 3

(C) Григор’єва, Н.С, Гуменюк, Л.О, Марчук, І.В., Собчук, Д.С., Шабайкович, В.А. 
лідерів світового ринку товарів класу люкс, оголосила, що готова запустити виробництво медичних масок на французьких заводах модних будинків Balenciaga I Yves Saint Laurent.

У Чехії винайшли фільтри [9] що потенційно здатні знищувати COVID-19 для вентиляційних систем, які допоможуть знезаражувати середовище у приміщеннях. Цей пристрій допоможе у боротьбі з коронавірусом, а людям дозволить нарешті зняти маски у приміщеннях. Над прототипом кілька місяців працювали інженери 3 одного із празьких університетів.

Боротьба медицини з пандемією коронавіруса є недостатньою. Немає кваліфікованого медичного персоналу, обладнання, оснащення, необхідних ліків, засобів захисту тощо. У багатьох селах і містечках України стан сільської медицини катастрофічний. Боротьба 3 коронавірусом в сільській місцевості проводиться ще гірше, що пов'язано з об'єктивними і суб'єктивними причинами, хоча там проживає біля $31,1 \%$ населення країни, де $є$ проблеми 3 доступом до медичної допомоги і саме там раніше селянам надавалась перша медична допомога. Найгірше, що стан медичної інфраструктури значно погіршився після «реформування» медицини екс-міністром МОЗ У.Супрун разом з лобістами з Ради, Уряду та іншими «затоками», які не розуміючи положення, помилково вважали, що економічно невигідно утримувати фельдшерсько-акушерські пункти на селі, в яких було зосереджено хоча i старе обладнання, оснащення, штат лікарів і середнього медичного персоналу, виконувались прості аналізи та надавались медичні послуги тощо. Цікаве «об'єднання» медичних закладів згідно реформи: наприклад, два заклади об'єднуються в один, але фінансування залишається тільки для одного. $€$ приклади, коли на функціонування одного закладу фінансування проводилось в складчину. Хоча всі знають про недоліки цього, «реформування» ніхто не збирається його відміняти. Цікаво, звідкіля та як підбираються такі бездарні керівники. На жаль порівняння системи з світовою не корисне для України і то по всіх напрямках. Викликає велике здивування, коли горе-керівники призначають додаткові спецпоїзди буцімто для вивозу туристів з червоних зон, тобто проводиться фактичне розповсюдження пандемії коронавірусу по всій країні, замість знищення його на місцях.

Після цього взялись за приватизацію чи вірніше «прихватизацію» медичної інфраструктури та особливо платних медичних послуг, тобто зайнялись бізнесом в медицині. При цьому значно зменшилась кількість медичних пунктів, медичного персоналу, медичних послуг, значно збільшились кошти на ліки в аптеках, до яких ще треба було добратись по поганих дорогах. Нанесена шкода очевидна. Держава навіть не виконала основного - забезпечення фінансової допомоги сільській медицині в боротьбі 3 коронавірусом. Відомі факти, коли виділені кошти на боротьбу з коронавірусом перекидались на ремонт доріг, інші цілі.

Почалася суцільна приватизація з іiі негативними наслідками. Наприклад, пройти КТ завдання не з легких: треба чекати від 3 до 10 днів, черги, збільшилась його вартість до 3 - 5 тис. грн, МРТ - до 5000 тис. і т.п. На тестування, обстеження та лікування тратяться шалені гроші, хоча все це повинно робитися безкоштовно і в першу чергу на селі по місцю проживання пацієнтів. На селах і надалі медичні пункти розташовані далеко один від одного, немає потрібних лабораторій, обладнання, оснащення, кваліфікованого медичного персоналу, а медичні послуги стали платними. Особливо подорожчали ліки, найдешевший препарат, що на $100 \%$ відшкодовує держава, коштує 5,22 грн, найдорожчий - 863,43 грн, хоча це не все: меробоцид коштує 100-200 тис. грн. Є і дорожчі препарати. Все це відштовхує особливо бідне сільське населення і не тільки від лікування. Родинна пара, яка лікувалась від коронавіруса вдома, заплатила 40 тис. грн, хоча заяви Міністра МОЗ Степанова М.В. про безкоштовні ліки і лікування хворих вдома залишаються балаканиною. Безплатне в медицині хіба що тільки співчуття і то не завжди.

Не важко по селах відновити кращу інфраструктуру медичного обслуговування, але ніхто цього не робить. Причина - відсутність фінансування, а також чомусь зацікавленості. Уряд мав би представити план збереження районних сільських лікарень та надання медичних послуг, наприклад, функції денного стаціонару. Прості аналізи можна робити в сільських лабораторіях, які можуть бути також мобільними, там же організувати правильну роботу сімейних лікарів, тестування тощо.

Зрозуміло, що до появи ефективних ліків, препаратів, способів лікування, вакцинація від коронавірусної хвороби буде малоефективною. На жаль, дієвим способом профілактики i реагування на поширення коронавірусної хвороби залишаються тільки обмежувальні протипандемічні заходи. Заходами боротьби з коронавірусом (рис. 3), є сама коронавірусна 
хвороба, виробництво продукції та соціальна сфера обслуговування. При цьому головним виступає медичний персонал 3 його мізерними зарплатами, які безумовно вимагають значного підвищення, на що держава не може собі дозволити 3-за поганого стану економіки i ii подальшого занепаду. Тут можна також віднести низьку кваліфікацію (яка плата, така праия!). Практика минулого показала, що 3-за об'єктивних і суб'єктивних причин часто відчувається дефіцит кадрів, тобто завжди повинен бути кадровий резерв, якого нема. Дуже багато медпрацівників по цих причинах виїхали за кордон, де успішно працюють на іншу країну.

Необхідним є профілактика та обов'язкове всеохоплююче тестування на коронавірус, засоби захисту, алгоритм лікування тощо. Без необхідних сучасних ліків і супутніх матеріалів ніякого покращення не передбачається. Надзвичайно важливим виступають наукові дослідження процесів, що вимагають високої кваліфікації дослідників і організації наукових лабораторій, центрів тощо, які відкриваються в передових країнах з високим рівнем економіки. Але головним вважається якість урядування та управління, яка $є$ явно недостатньою, та кваліфікованість.

Замість хімічної обробки, воду чи повітря опромінюють ультрафіолетовим світлом, яке $\epsilon$ ефективним: віруси, бактерії та інші мікроорганізми знищуються ультрафіолетом за лічені секунди. Адже таке випромінювання пошкоджує геном мікроорганізмів, через що збудники хво-роб не можуть далі розмножуватися.

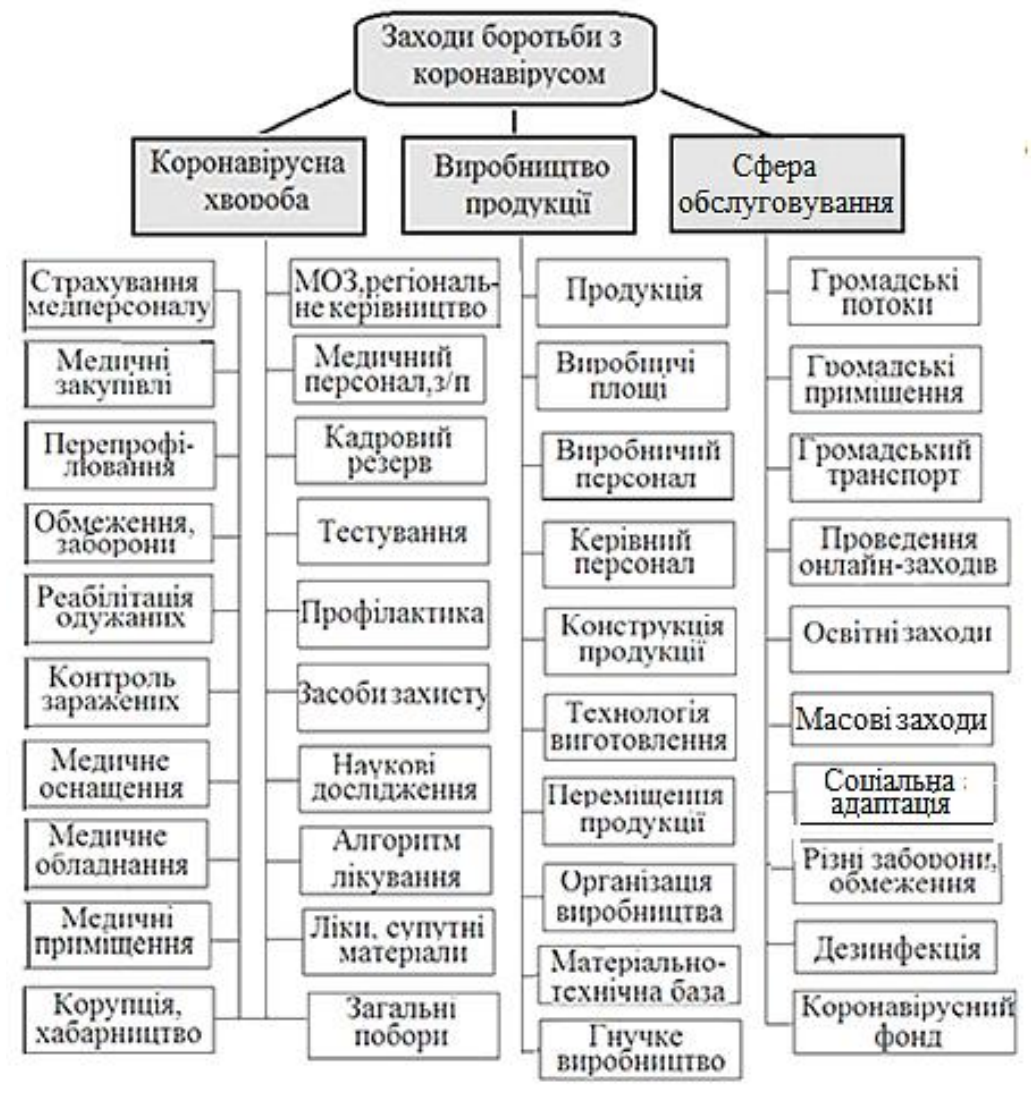

Рис. 3. Заходи боротьби з пандемією коронавірусу

Під час пандемії коронавірусу, який зокрема передається через аерозольні частинки вологи у повітрі, до дезінфекції за допомогою ультрафіолету прикута особлива увага. Використовують нові ультрафіолетові лампи [10], які створюють дезінфекційну варству під стелею, де циркулює та очищується повітря. До цього при використанні використанні світла ультрафіолетових ламп у приміщеннях доводилося усіляко уникати його потрапляння на людину, оскільки воно є шкідливим для здоров'я.

Велике значення мають не тільки засоби індивідуального захисту: костюми безпеки, ізоляційні халати, маски, захисні окуляри, щитки, рукавички, респіратори тощо. Особливо корисною є ультрафіолетова лампа Care 222 [11], яка вбиває коронавірус в приміщенні. Про це повідомляє Kyodo News. Ïї можна використовувати для дезінфекції приміщень, де постійно 
знаходяться люди, наприклад, в автобусах, поїздах, ліфтах, офісах. Нова лампа випромінює ультрафіолетові промені $з$ довжиною хвилі 222 нм замість звичайних 254. Це робить їх смертельними для коронавіруса, але нешкідливими для людини. Ефективність 222нанометрових УФ-променів у підтвердили також наукові дослідження.

Наступну групу заходів становить стан медичних приміщень, обладнання, оснащення та наявність необхідної ефективної апаратури. Важливими є обгрунтовані обмеження, заборони, карантинні заходи, штрафи і фінансова підтримка в першу чергу як зі сторони держави, так і різних фондів, спонсорів тощо. Декілька слів про прості одно- чи багатоварстні маски. Порівнюючи розміри коронавіруса (80-220 нм) і мкм тканини та прохідне січення таких масок, легко прийти до висновку про їх малу ефективність, особливо при кашлі, чиханні тощо, коли коронавірус ще не зосереджений на каплях.

Дезінфекція має бути не тільки повітря, зводитися до простого протирання поверхонь, як широко показують, але i використання дезінсекції та дератизації приміщень, обладнання,транспорту, що знищують віруси. Тут треба згадати низьку свідомість пацієнтів, які борються з пандемією, але в більшості недостатньо. При розробці заходів боротьби 3 коронавірусом у керівництва відсутня фаховість захисту та особливо його виконання.

Значну шкоду лікуванню взагалі, а коронавіруса зокрема, завдають бізнес, корупція, хабарництво, а особливо загальні побори, які значно поширились на грунті надзвичайно низьких зарплат i поганої організації робіт. Успішне вирішення будь-яких питань супроводжуються хабарами, а «безкоштовна» медицина є фікцією. Хворі вже давно ліки закуповують в аптеках самостійно, але навіть їх використання (бинти, уколи, крапельниці і т.п.) оплачується пацієнтами. Всі процедури платні. За відгуками хворих тепер один день в лікарні в залежності від важкості хвороби обходиться 10-30 тис. грн і це тільки мінімум. У лікарнях України справжня катастрофа: не вистачає місць хворих на Covid-19, пацієнти лежаь у коридорах, їдальнях, вільних місць немає, на кисень не вистачає кисневих балонів, всюди черги, реанімація постійно переповнена, смерті майже щодня. Змінити таке становище в медицині можна як за рахунок підвищення зарплат, так і адміністративного та кримінального переслідування, як це, наприклад, було зроблено в Польщі та інших країнах. При цьому треба обов'язково враховувати результативність лікування. Приємним виключенням 3 цього $є$ приклад функціонування військових госпіталів, в яких частина зловживань значно менша.

Особливе значення має вакцинація для захисту від коронавірусної інфекції COVID-19 в системі охорони здоров'я. Необхідно вакцинувати понад 70\% населення планети, щоб пандемія коронавірусу припинилась. Відомі вакцини BNT162b2 створені у співпраці фармкомпаній Pfizer (США) i BioNTech (Німеччина) 3 ефективністю $95 \%$. Інша вакцина Moderna (США) створена у співпраці фармкомпаній Pfizer i BioNTech має ефективність 94,5\%. Вакцина Moderna (США) mRNA-1273 має також високу ефективність 94,5\%. Зараз відомо більше 50-ти таких препаратів. До квітня 2021 року було заплановано виготовити 145 млн доз цієї вакцини. Двокомпонентна двовекторна вакцина Супутник V виготовлена Росії. Заявлена ефективність за офіційними даними - $92 \%$ " Світові ЗМІ наголошують на сумнівах щодо безпеки цього препарату з огляду на інформацію, що Росія пропустила важливі етапи розробки і не навела наукових даних про випробування вакцини, але це питання більше політичне. Масова вакцинація в Росії почалась 5 грудня 2020 року, вартість вакцини - близько \$20, для населення країни препарат $є$ безкоштовним. Особливу увагу до себе привернула оксфордська вакцина ChAdOx1 під кодовою назвою AZD1222 фірми Vaccitech, розроблена британсько-шведським фармаконцерном AstraZeneca у співпраці 3 Оксфордським університетом. Оксфордську вакцину ChAdOx1 вважають одним із фаворитів у боротьбі з пандемією COVID-19. Низка урядів уже попередньо замовила іii. Насправді розробкою вакцини займається ще більша кількість компаній. Наприклад, шведсько-британський фармацевтичний велетень AstraZeneca, або Johnson \& Johnson. Тим часом у Китаї розробляють одразу кілька вакцин проти нового коронавірусу. Компанія Sinovac Biotech розробила вакцину CoronaVac. Більшість вакцин викликають незначні побічні ефекти. По суті, це імунна та запальна реакції організму на вакцину.

Відома нова заявлена ефективна вакцина, яка зупиняє цитокіновий шторм на основі моноклональних антитіл REGN-CoV2 Bamlanimab i протизапальний Baricitinib, які вже дозволені у ЕС і США. Але у нових штамах вірусів поки що невідомо чи вказані вакцини будуть ефективними, швидше всього ні. 
До недоліків вакцинації можна віднести наявність великої кількості різноманітних вакцин з різними характеристиками, хоча відомо, що в таких випадках вибираються найкращі, які і рекомендуються до виготовлення та для вакцинації. Різноманітність вакцин відкрила дорогу до їх націоналізації та політизації, що недопустимо. Тут також можна відмітити шахрайство та корупцію як при їх виготовленні, так і розприділені. Тільки на Україні Уряд може назначити дату вакцинації вакциною, якої ще взагалі нема в державі. Опускаючи різні ліки, на яких наживається аптечна мафія, оказується навіть продаються фіктивні довідки про результати тестування, потрібні для видуманих цілей (поїздки, прийом на роботу тощо). Їх поява обгрунтована меншою ціною в рази, ніж державною та бажання збагачення.

Масштабну шахрайську схему розробили у двох київських столичних медичних університетах: студентам-двієчникам продавали сертифікати професійної компетентності системи «Крок» на продовження навчання (газета Експрес №7 [10554] 18-25.02.2021). За «послугу» студенти платили 3 тис. \$, іноземці - 5 тис.\$. На цьому шахраї заробляли мільйони доларів. Страшно навіть подумати, якими лікарями вони будуть в майбутньому?

3 метою покращення боротьби 3 коронавірусом почали застосовуватись локдауни, які практично мало що дають і в яких немає ні краплі логіки, ні грама здорового глузду. Якою хворобою заразилось керівництво, яке накладає ряд нелогічних обмежень типу заборони працювати магазинам 3 непродовольчими товарами, в тому числі заборона купівлі ні шкарпеток, ні батарейок, поїздок на курорти (наприклад курорт Буковель, де відпочивав Президент і море бізнесменів?). Навколо вакцини проти коронавірусу COVID-19 відчувається також якась хімія: незрозуміле втручання держави у вибір постачальника препарату, особисто Прем'єр-міністра, хоча це функція виключена така зацікавленість, також в одній зі схем збагачення.

Непрофесійне та випадкове фінансування боротьби з коронавірусом підтверджує використання фонду боротьби з ним 66 млрд грн [12], який Кабмін заснував в квітні 2020 р. в розпал жорсткого карантину. Цей фонд ніякого відношення до боротьби з коронавірусом не мав, гроші розтринькали на інші цілі. Для порівняння: МО в 2020 р. виділено 117,6 млрд грн, МО3 - 115,7 млрд грн, МВС - 93,4 млрд грн, Міносвіти - 43,2 млрд грн. Понад 14 млрд грн 3 фонду спрямовані МО3, Мінекономіки і Мінсоцполітики, які отримали 6,9 млрд грн і 3,4 млрд грн відповідно. Найбільш резонансним стало виділення 54,1\% коштів 3 коронавірусного фонду на дороги, що продовжується i надалі. Помилково вважають, що достатнє забезпечення пріоритетних напрямків охорони здоров'я та соціального захисту громадян дозволило спрямувати кошти фонду на ремонт і утримання автодоріг. Крім "коронавірусних" 35 млрд грн в поточному році на дорожнє господарство направлено 69 млрд грн 3 державного дорожнього фонду та 4,4 млрд грн кредитів від міжнародних фінансових організацій. Крім цього, Укравтодор отримав державну гарантію на суму 19,3 млрд грн для забезпечення запозичень на відновлення автодоріг. При цьому, гроші фонду не освоєні, що говорить про не ефективне планування різних робіт. Поки Укравтодор і МВС проїдають Коронавірусний фонд, МОЗ само не дуже активно використовує ці кошти. 3 виділених на медицину 14,3 млрд грн станом на 22.09.2020 р. освоїли лише 519 млн (3,6\%). Гроші витрачали на забезпечення лабораторій МО3 та закупівлю засобів індивідуального захисту. Але на 24.09.2020 р. обіцяні виплати надбавок

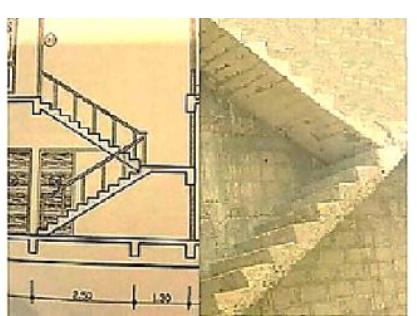

Рис. 4. Результат проектування сходів інженером-будівельником після його дистанційного навчання лікарям не розпочато.

На це з фонду боротьби з COVID-19 виділили 5,9 млрд грн. Тепер Україна від СС отримала перший транш у 600 млн євро 3 програми допомоги на 1,2 млрд євро. МВФ відмовив Україні в наданні кредиту на суму $\$ 2,2$ млрд 3-за відсутності прогресу в реформах.

В умовах пандемії правильним і необхідним $є$ проведення онлайн-заходів для людей, які мають прямий особистий контакт між собою при вирішенні питань, що повстають, безмасових заходів і різних заборон, обмежень тощо. Онлайн-заходи мають безумовно велике значення, але при відповідному обгрунтованому застосуванні, наприклад, проведення конференцій, зустрічей, нарад тощо. Зовсім непридатне використання онлайн-заходів при навчанні, що приведе до зниження його якості, яка у нас і так невисока. Це можна коротко проілюструвати рис. 4 при проектуванні сходів інженером-будівельником після його дистанційного навчання [13], які

(C) Григор’єва, Н.С, Гуменюк, Л.О, Марчук, І.В., Собчук, Д.С., Шабайкович, В.А. 
виглядають ніби правильними, але мають суттєву помилку. Що б не придумувати, але для користі та ефективності, навчання має бути традиційним, очним, а не заочним чи дистанційним.

Великою помилкою було закриття транспортних потоків, громадського транспорту, сфери обслуговування тощо, що продовжується i тепер. Це як би перекрити судини в людському організмі, хоча природа підказує, що їх треба тільки чистити чи міняти.

Коронавірус вплинув не тільки на навколишне середовище, але і на всі сфери життя через суспільно-політичну сферу, виробництво, сферу послуг тощо. Особливо постраждала економіка: змінилася структура попиту та пропозицій, глобалізація стала регіоналізацією та локальним протекціонізмом, піднялась ціна активів, відновилось самозабезпечення необхідними товарами, енергоресурсами тощо. Знизилась ділова активність, впав ВВП, скоротились витрати, споживання, персонал організацій, зріс IT-сектор, кількість зайнятих у ньому і частка у ВВП підвищилася ефективність бізнесу тощо. Прогнозується зростання ВВП України у 2021 році на 4,1\% при інфляції 6,9.

3 початку пандемії падіння ВВП склало 6-8\%, а на кінець року прогнозується ще 3,7\%. Український ВВП можливо впаде більше ніж світовий на 4,2 \%. ВВП України через пандемію COVID-19 скоротиться на 7\% у 2020 році внаслідок впливу на економіку зовнішніх та внутрішніх шоків. Песимістичниц̆ прогноз передбачає триваліші карантинні заходи в Україні та сильніші зовнішні та внутрішні шоки, за рахунок чого економіка зменшиться навіть на $11,2 \%$ ». За оцінкою МВФ, українська економіка зменшиться за підсумками 2020 року на 8,2\%. Спочатку в міністерстві економіки говорили про падіння ВВП на 3,9\%. Проте в останньому прогнозі Уряд збільшив цей показник до 4,8\%.

Правда, жоден світовий аналітичний центр чи інвестбанк не здатний швидко оцінити масштаб трансформацій, оскільки це залежить від багатьох чинників, що динамічно змінюються. При цьому біоінженерія стане новим хайповим сектором світової економіки, зміниться ії структура та логістики, будуть змінені ключові локації виробництв, збільшиться розрив між багатими і бідними країнами. Багаті країни обмежать бідних в доступі до технологій, зміниться система охорони здоров'я. Ї̈̈ частка у ВВП має зрости. Алгоритми медичних сервісів також зміняться, збільшуючи на них витрати. Дедалі більше уваги приділятиметься профілактиці пандемії та превентивним заходам.

На коронавірусну хворобу може захворіти від 40\% до 60\% населення планети. При цьому багато хто у легкій формі, що не створює їм дискомфорту, найімовірніше буде кілька хвиль протягом року. Вже сьогодні є більше 50 різновидів вірусу, який мутує постійно, а це як кажуть, підтверджує штучність його походження (біологічна зброя ?) і також не гарантує, що людина, перехворівша на коронавірус, чи отримала щеплення не захворіє іншим його штамом. 3 початку вакцинації проти COVID-19 в світі вже зробили близько 312 млн щеплень в 116 країнах. В середньому вводять по 8,08 млн доз щодня. Ефективність невисока, що свідчить про якісь недоробки ?.

В майбутньому, коли будуть знайдені ліки від коронавірусу та паралельно від багатьох інших захворювань, стануть нормою віртуальні сервіси та дистанційна робота, наради, перемовини тощо, знизиться частка людської праці в логістиці, комунікаціях, сервісі, в тому числі державному. Криза триватиме ще довго та залежатиме від багатьох причин. Як показує структура коронавіруса, можна припустити, що успішний напрямок майбутніх ліків повинен бути направлений на знищення функціонування білкових шипів, як мостика від віріона до поверхні клітин людини. Другою підказкою $є$ знищення коронавіруса шлунковим соком в шлунку, які чомусь не розглядається. Підказкою також може бути особливості утворення зовнішньої форми вібріона (структури) тощо.

В кінці року Держаудит служба розпочне державний фінансовий аудит виконання бюджетних програм боротьби 3 хворобою COVID-19 та іiі наслідками, спричиненою коронавірусом SARS-CoV-2 за 10 місяців 2020 р. Цікаво чи буде опубліковано, скільки грошей було розкрадено і саме ким?

Велика смертність від коронавірусу, більше 2,5 млн. людей, викликає багато питань до керівництва: причини непідготовленості до пандемії, куди поділись мільярди від податків, чому так повільно проводиться вакцинація, чому не всім доступна вакцинація, чому закуповується менш ефективна та більш небезпечна вакцина та багато інших. Сім країн світу відмовились від щеплення вакциною AstraZeneca (Естонії, Латвії, Австрії, Данії, Литві та Люксембурзі) по причині побічних ефектів, в основному тромбозу. Тепер Україна схвалила китайську вакцину 
Sinovac від коронавірусу, що по розповсюдженню не є кращим варіантом. Але саме більше зло, коли боротьба 3 пандемією перетворилась в нову бізнес-стратегію, навіть індустрію? Відомо, що в таку боротьбу світ вже витратив 16 трлн дол., а це біля 20\% глобального ВВП, розміри економіки таких країн як чотири Німеччини, 11 Росій, або в п'ять разів більше світового нафтогазового бізнесу. Безліч компаній та окремих любителів швидкої наживи включились за здобуття цих фантастичних ресурсів. Значно збагатилась фармацевтика та виробники санітарно-гігієнічних засобів, масок, медичних тестів тощо. Суми медичних закупівель повсюди значно збільшились.

\section{Висновки.}

Неочікувана поява пандемії коронавіруса показала повну непідготовленість МО3 і його підрозділів, поліклінік і лікарень до боротьби 3 нею, а також виробництвом і соціальною сферою. Недостатній медичний персонал, обладнання та оснащення, відсутність методики лікування та багато іншого потрібного. Замість боротьби 3 пандемією продовжилось впровадження невдалої медичної реформи, почалось закриття чи скорочення виробництва, звільнення персоналу чи виплати компенсацій без виходу на роботу, закриття громадських потоків, надумані необгрунтовані заборони і обмеження тощо. Проявилась повна відсутність науково-дослідних результатів як по коронавірусу, так і пандемії. В результаті низької кваліфікації все робилося навпаки, що привело до розширення пандемії.

Для боротьби з пандемією коронавіруса необхідний фаховий обгрунтований план забезпечення як результатами досліджень, так і потрібним медичним персоналом, обладнанням i оснащенням, жорстким контролем його виконання, що зараз відсутнє. Безумовно на першому місці має бути кваліфікація розробників і виконуючого персоналу. При цьому витрати обов’язково повинні бути сумірними з результатами від їх застосування.

\section{Інформаційні джерела}

1. Анча Баранова. Коронавірус Інструкція з виживання. Вид-во Наш формат. - 2020. -155 с.

2. Кулицький С. Проблеми розвитку економіки України, обумовлені пандемією коронавірусу COVID-19 у світі, і пошук шляхів їх розв'язання (Початок, закінчення див. у № 9) [Електронний ресурс] / С. Кулицький // Україна: події, факти, коментарі. - 2020. - № 8. - С. 53 63. - Режим доступу: http://nbuviap.gov.ua/images/ukraine/2020/ukr8.pdf.

3. Boeing зменшить виробництво і скоротить персонал у зв'язку з коронавірусом. [Електрон ний ресурс]. - 2020. Режим доступу до ресурсу: https://ua.interfax.com.ua/news/ economic /658882.htm.

4. Великі автомобільні компанії призупинили виробництво в Свропі через Коронавірус. [Електронний ресурс] -2020. - Режим доступу до ресурсу: https://dt.ua/WORLD/velikiavtomobilni-kompaniyi-prizupinili-virobnictvo-v-yevropi-herez-pandemiyu-341780_.html.

5. Маска, що діагностує зараження коронавірусом. [Електронний ресурс] -2020. - Режим доступу до ресурсу: http://www.moyby.com/news/408738/.

6. Антибактеріальна маска 3 графену. [Електронний ресурс]: - 2020. Режим доступу до pecypcy: https://cikavosti.com/vcheni-rozrobili-antibakterialnu-masku-z-grafena/.

7. Багаторазова маска з підігрівом. [Електронний ресурс]: - 2020. Режим доступу до ресурсу: https://socportal.info/ru/news/uchenye-sozdali-mnogorazovuiu-masku-s-podogrevom-otorayaunichtozhaet-virusy/.

8. Світові компанії змінили профіль 3-за коронавіруса. [Електронний ресурс] -2020. - Режим доступу до ресурсу: [https://ua.112.ua/golovni-novyni/antyseptyk-zamist-alkoholiu-yak-svitovikompanii-zminyly-profil-z-za-koronavirusa-531615.html].

9. Унікальні фільтри для вентиляційних систем. [Електронний ресурс]. - 2020. Режим доступу до ресурсу:https://www.you tube.com/watch?v=aiG8MUlQcrY\&feature=emb_rel_end

10. Безпечне ультрафіолетове випромінювання знищує SARS-Cov-2. [Електронний ресурс] 2020. - Режим доступу до ресурсу: https://mister-blister.com/issledovanie-pokazyvaet-chtobezopasnoe-ultrafioletovoe-izluchenie-effektivno-ubivaet-SARS-CoV-2/.

11. Ультрафіолетова лампа Сare 222. [Електронний ресурс]. - 2020. Режим доступу до pecypcy: https://medprofi.com.ua/baktericidnye-recirkulyatory.

12. Будівництво під час чуми. На що пішли гроші з фонду боротьби 3 коронавірусом. [Електронний ресурс], -2020 - Режим доступу до ресурсу: https://focus.ua/economics/464333bolshaja-strojka-fond-koronavirus-ukraina. 
13. Сходи, запроектовані інженером-будівельником після його дистанційного навчання. [Електронний ресурс], -2020 - Режим доступу до ресурсу: https://m.facebook.com/779444322118682/photos/a.779453625451085\%20/3465427606853660/?type $=3 \&$ refid $=52 \& \_$tn_ $=E H-R$

\title{
ВЛИЯНИЕ ПАНДЕМИИ КОРОНАВИРУСА НА ПРОИЗВОДСТВО И МЕДИЦИНСКОЕ ОБСЛУЖИВАНИЕ
}

Григорьева Н.С., Гуменюк Л.О., Марчук И.В., Собчук, Д.С., Шабайкович В.

Луцький національний технічний університет

Рассмотрены меры борьбы с пандемией коронавируса при лечении заболевания коронавирусом, с организацией нормального функционирования производства и адаптации социальной сферы обслуживания. Первое направление - основное, связанное с мерами подготовки медицинского персонала, лекарств, оборудования, оснастки, специалистов-врачей, тестирования, вакцинации. Это достигается исключительно при комплексном анализе и синтезе уровня медицины, конструкции и технологии изделий производства, его организации, внутренней и внешней среды. Обеспечение нормального функиионирования производства достигается путем его реорганизачии, дезинфекиии производственных мощностей, использование автоматического оборудования и оснастки, защита производственного персонала. Изменения в сочиальной сфере обслуживания включают ее адаптачию к пандемии коронавируса, реорганизации транспортных потоков, услуг, запреты, ограничения и приспособленность к окружающей среде. Обязательный учет причин пандемии коронавируса.

Ключевые слова: коронавирус, пандемия, мероприятия, запреты, ограничения.

\author{
N. Grigoryeva, DSc., PhD., Eng., prof., L. Humeniuk, Ph.D., I. Marchuk, Ph.D., \\ D. Sobchuk, Ph.D.Eng, W. Shabaykovich, DSc., prof.Eng.
}

\section{THE IMPACT OF THE CORONAVIRUS PANDEMIC ON PRODUCTION AND MEDICAL SERVICE}

Measures to combat the coronavirus pandemic in the treatment of the corona-virus disease, with the organization of the normal functioning of production and adaptation of the social service sector are considered. The first direction is the main one, connected with measures for the preparation of medical personnel, drugs, equipment, equipment, medical specialists, testing, vaccination. This is achieved exclusively through a comprehensive analysis and synthesis of the level of medicine, design and technology of production products, its organization, internal and external environment. Ensuring the normal functioning of production is achieved by its reorganization, disinfection of production facilities, the use of automatic equipment and tooling, protection of production personnel. Changes in the social service sector include its adaptation to the coronavirus pandemic, reorganization of traffic flows, services, bans, restrictions and adaptability to the environment. Mandatory consideration of the causes of the coronavirus pandemic.

Key words: coronavirus, pandemic, events, bans, restrictions. 